\title{
Bee Smoke Paper Dosage Form
}

National Cancer Institute

\section{Source}

National Cancer Institute. Bee Smoke Paper Dosage Form. NCI Thesaurus. Code C149354.

Pharmaceutical impregnated strips that deliver the active substance(s) when lit. This is used to treat bee hives and nests. 